\title{
16
}

\section{One thousand years of human environmental transformation in the Gambier Islands (French Polynesia)}

\author{
Eric Conte \\ Centre International de Recherche Archéologique sur la Polynésie, \\ Université de la Polynésie Française, French Polynesia \\ eric.conte@upf.pf
}

Patrick V. Kirch

Departments of Anthropology and Integrative Biology,

University of California, Berkeley, USA

\section{Introduction}

Landscapes and their biodiversity result, to be sure, from natural processes (geological, biological), but also from the actions - direct and indirect - exercised by humans on their habitat over time. It is important, therefore, to take into account this historical dimension of the interactions between humans and their habitat, to better understand contemporary situations, and hopefully, to gain information which might aid in the better management of resources.

The islands of the eastern Pacific, distant from continental influence and settled very late by humans (during the past 3000 years or fewer), offer 'model systems' (Kirch 2007a, 2007b) where it is possible to study, in large part thanks to archaeological excavations, ecological conditions before the arrival of humans and following human influence. These islands provide less complex histories than continents that have been overrun and modified by our species over hundreds of thousands of years. We can also assess the impact of human arrival on these fragile environments which were formerly isolated, and follow over the longue durée the dynamic relationships between the colonising human populations and their island ecosystems. Since 2001, an international program has been carried out in the Gambier Islands (Figure 1), with our colleague Atholl Anderson participating in the first season of field research. One of the main objectives of this program has been the reconstruction of landscapes and the relationships between humans and their habitat over time (Conte and Kirch 2004). 


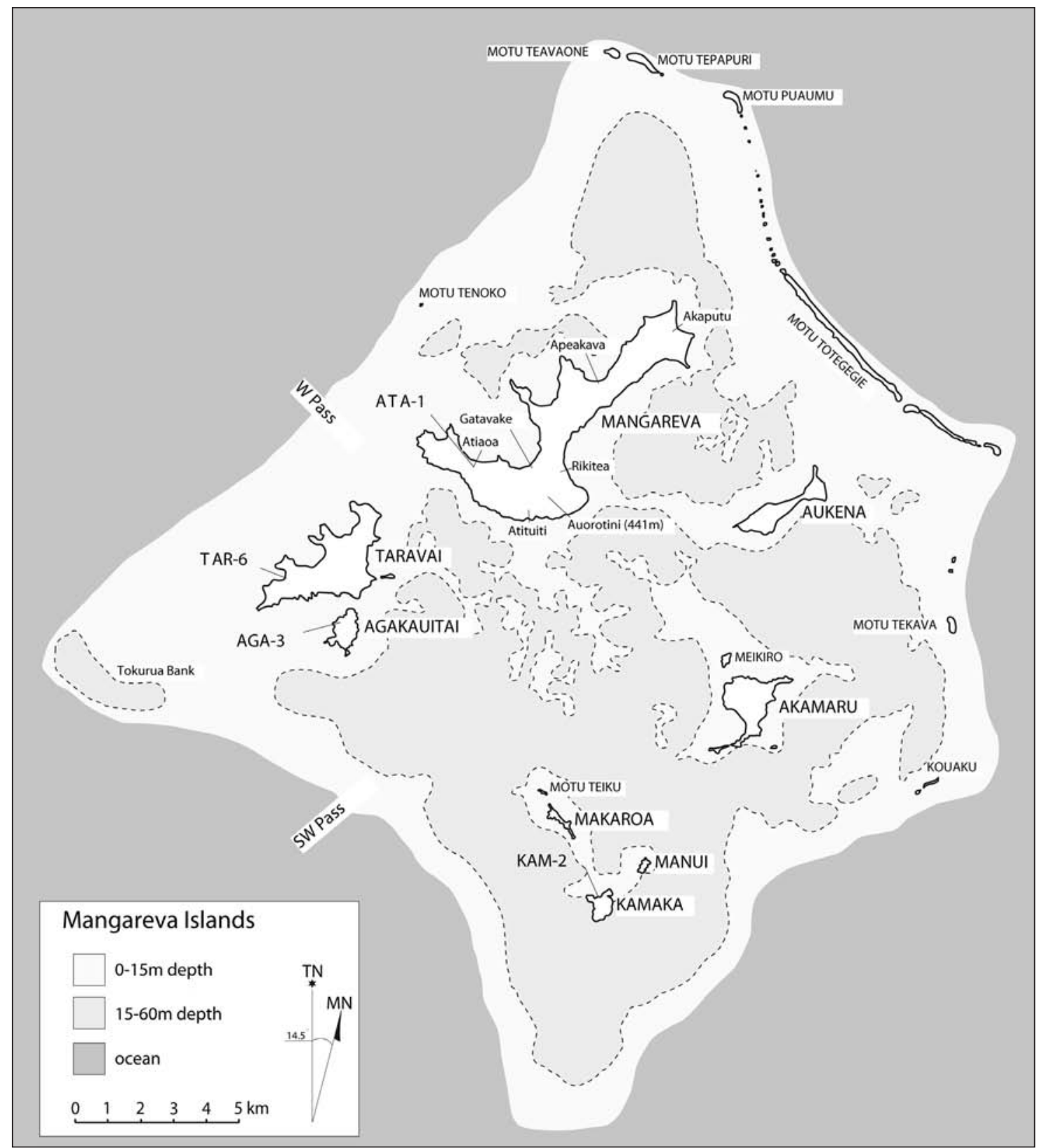

Figure 1. Map of the Mangareva Islands, showing the location of excavated sites.

\section{The Gambier Islands: An unusual environment}

At the eastern extremity of French Polynesia, this archipelago presents unusual characteristics which make this case study especially interesting. Enclosed by the same barrier reef, 10 small high islands (Figure 2) are the vestiges of the collapsed crater of a large volcano, of which the former caldera constitutes the present lagoon. While the land area is limited and the terrestrial habitat impoverished, the immense lagoon and reefs present a rich marine fauna. Historically, the steep slopes and ridges are destitute of primary forest, and are covered in pyrophytic Miscanthus cane and Dicranopteris ferns, while the vegetation of the small valleys and coastal plains is dominated by economic plants, largely introduced by the Polynesians (e.g. coconut, breadfruit, Hibiscus tiliaceus, Pandanus). This degradation of the vegetation on the hills is not a recent phenomenon, having been observed by Captain Wilson, the first European to arrive at the island, in May 1797. More generally, in 1934, the botanist of the Bishop Museum's Mangarevan Expedition 
bemoaned the total destruction of the indigenous flora (St. John 1935). Nonetheless, the islands are noteworthy for having at one time possessed a rich endemic fauna of terrestrial gastropods (including at least 38 endemic species in the families Achatinellidae, Endodontidae, Punctidae, Euconulidae, and Assimineidae). These endemic taxa are known only from sub-fossil specimens in recent sedimentary contexts, suggesting a major phase of extinction (Bouchet and Abdou 2003:169).

We have attempted to establish a chronology for this drastic environmental transformation, and have addressed ourselves to the matter of the factors both natural (such as climate change) and cultural responsible for these changes. Another question concerns the domestic dog and pig. Widely introduced throughout the Pacific Islands by people, these animals were not observed in the Gambiers by the first European visitors. Were these important domestic animals formerly present in the Gambiers, and if so, when and why did they disappear?

In contrast to the impoverished terrestrial habitat, the richness and diversity of the marine resources are notable, with, for example, 246 species of fish and 20 species of molluscs (Fourmanoir et al. 1974; Salvat 1974; Richard 1974). This does not stop us from asking whether human predation had significant consequences for these marine resources, a topic we also address below.

\section{Ethnographic sources and archaeological evidence}

After descriptions of the first explorers and missionaries, notably those of Père Laval (1938), very little ethnographic or archaeological work was carried out in the Gambier Archipelago during the first half of the 20th century. The primary work was conducted by Hiroa (1938) and Emory (1939) in 1934, during the Mangarevan Expedition of the Bishop Museum. But Emory was only interested in surface architecture (such as the remains of marae), and in searching for artefacts through his rather crude excavations in rock shelters. His work thus provides little information useful for our project. Not until 1959, with the research of Roger Green, did stratigraphic excavations using rigorous methods commence, yielding relevant evidence. Green excavated in five rock shelters on three islands: two on Kamaka, two on Aukena, and one on

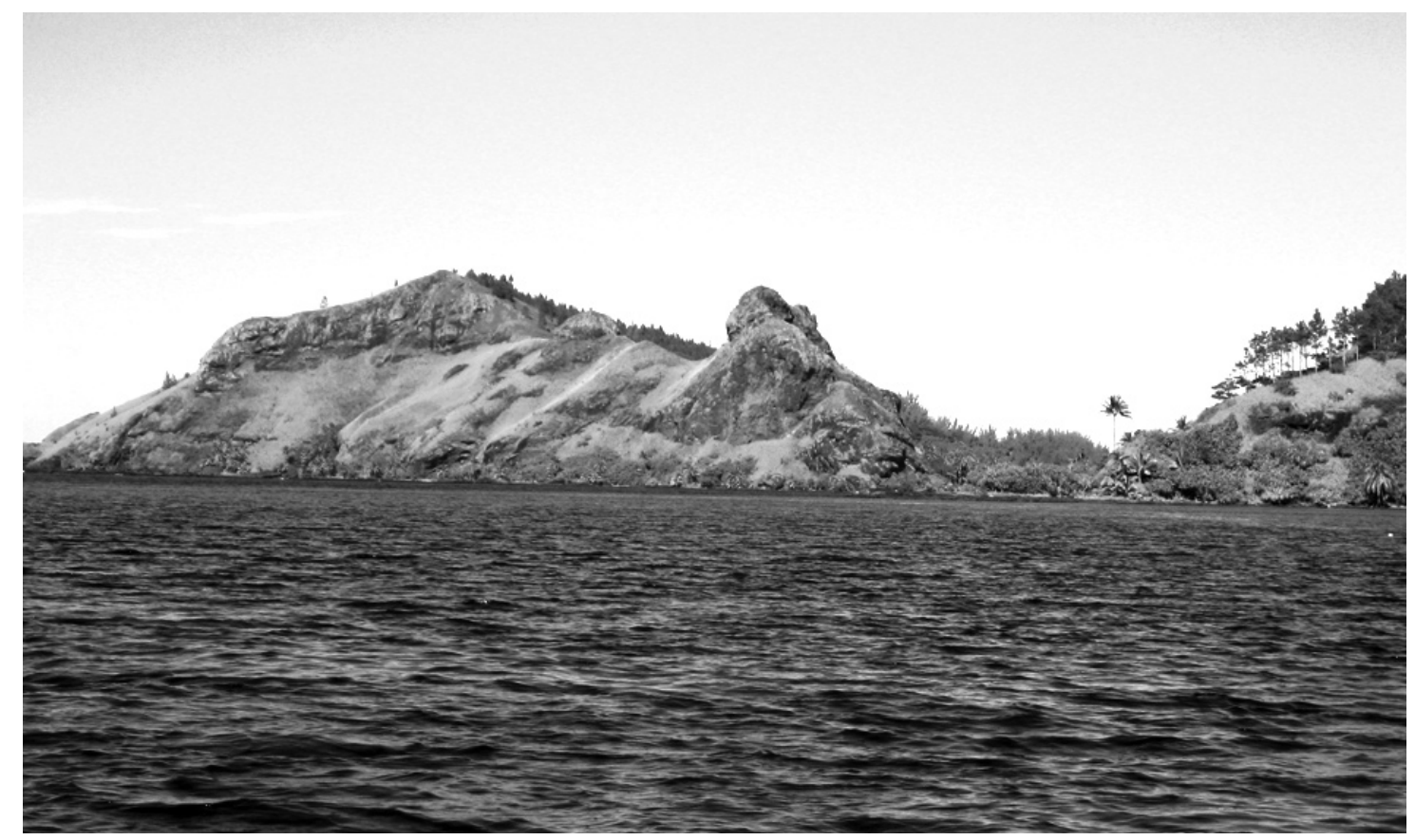

Figure 2. Island landscape: View of Agakauitai Island from the north. 
Mangareva. Green's work remained largely unpublished until recently, although he has now issued a series of reports and articles on the results of his 1959 excavations (Green and Weisler 2000, 2002, 2004).

In April-May 2001, M. Orliac made a research trip with the stated objective of studying the 'composition and evolution of the flora' of the Gambier Islands (Orliac 2002, 2003). Focusing his work on the coast and littoral zone of Mangareva Island (the largest island), especially in the Gatavake and Rikitea (and Atirikigaro) areas, he discovered a buried cultural deposit, dating between AD 1030 and AD 1290. This deposit included artefacts (e.g. fishhooks, pearl-shell graters) and plant remains characteristic of coastal trees. Since launching our research program in the Gambiers in 2001, three seasons of fieldwork have been carried out. All of the principal islands have been reconnoitered, more or less thoroughly. Among the different sites investigated, several have provided information relevant to the questions posed above; we briefly review the key sites below, followed by a discussion of general trends in the evolution of the Mangarevan environment.

\section{Onemea: A colonisation-phase site}

The site of Onemea consists of cultural deposits in an aeolian dune at the mouth of a small valley on the southwest coast of Taravai, the second largest island. As shown in Figure 3, recent shoreline erosion had exposed cultural materials, and we excavated two test pits, of $1 \mathrm{~m}^{2}$ each, in 2003, and an additional 10 test units in 2005. However, our analysis of the 2005 materials is still in progress, hence we restrict our discussion to the materials obtained in 2003, especially those from TP-2, which yielded the most important information relative to the early phase of human ecology in Mangareva. The stratigraphy of TP-2, visible in Figure 4, comprised three layers, as follows:

Layer I: A brown, organically enriched layer about $15 \mathrm{~cm}$ thick.

Layer II: The main cultural deposit, consisting of greyish sand with considerable charcoal and oven stones, about $40 \mathrm{~cm}$ thick.

Layer III: Yellowish-orange aeolian sand, containing a high density of bird bones, particularly in the $15 \mathrm{~cm}$ immediately underlying Layer II, although bird bones extended down to about $115 \mathrm{~cm}$ below surface. Layer III was tested to a depth of $175 \mathrm{~cm}$.

Three radiocarbon dates were obtained from TP-2 (Conte and Kirch 2004:Tables 4.1 and 4.2). A sample from the interface of Layers I and II, and thus probably dating the latest phase of occupation, returned a calibrated age of AD 1250-1280 (Beta-190119). A lens of fine charcoal at the base of Layer II, just above the contact with Layer III, was dated to cal AD 1000-1030 (Beta-190118). Finally, a sea-bird bone (Procellariidae) from $103 \mathrm{~cm}$ below surface within Layer III was dated to cal AD 1000-1050 (using the marine calibration curve with a DeltaR of 0). These ages suggest the Onemea site was occupied between about AD 1000 and AD 1200, which fits quite well with other recent radiocarbon dating of colonisation-phase sites in southeastern Polynesia (Anderson et al. 1999; Anderson and Sinoto 2002; Conte and Anderson 2003).

\section{Nenega-Iti and Atiaoa: Two intermediate-period sites}

Two sites correspond to an 'intermediate' period in the archipelago's history, between initial human colonisation and the late period immediately preceding European contact. Both of these are small rock shelters, on the islands of Agakauitai and Mangareva.

In the Nenega-Iti rock shelter on the western side of Agakauitai, we excavated a single test pit of $1 \mathrm{~m}^{2}$. Despite some perturbation of the surface of the rock-shelter floor by pigs, the underlying cultural deposit is intact and well stratified, with four distinct cultural layers, and 


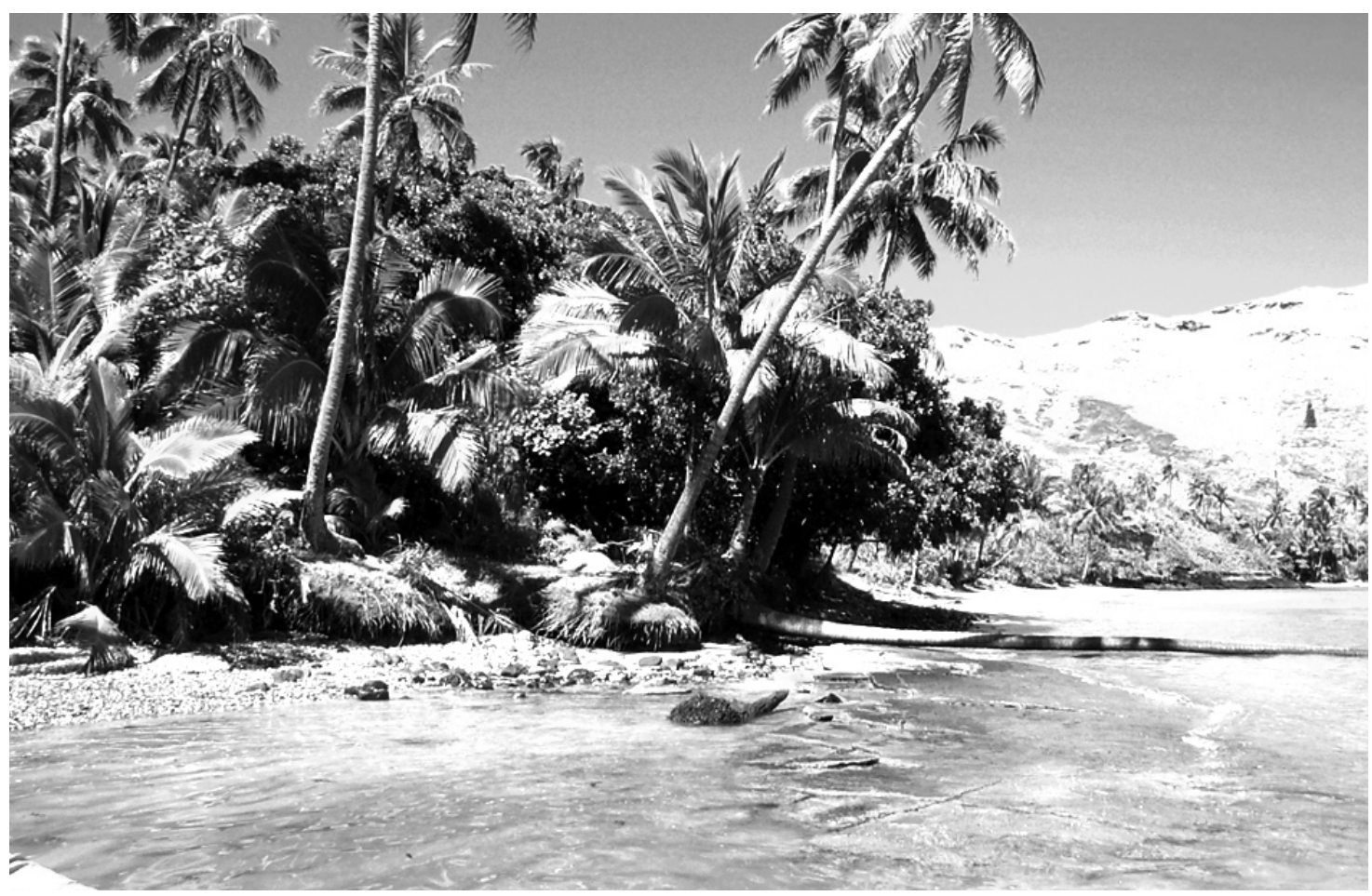

Figure 3. View of the Onemea dune site (TAR-6) from the shore.

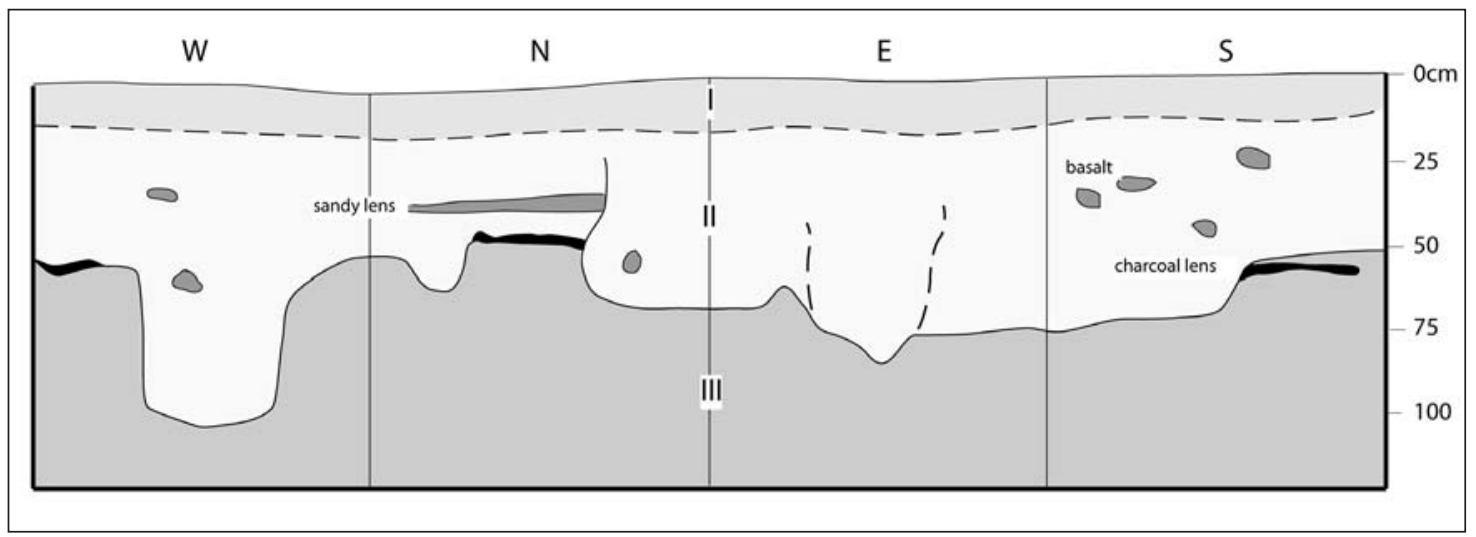

Figure 4. Stratigraphy of Test Unit 2 in the Onemea site.

multiple lenses of charcoal and ash, indicating considerable hearth and/or earth-oven activity in the shelter. The main cultural layers (Figure 5) are as follows:

Layer I $(0-4 \mathrm{~cm})$ : Very dark-grey, fine-grained sandy loam, containing midden material, but somewhat disturbed by pig rooting.

Layer II $(4-10 \mathrm{~cm})$ : Dark-grey clay loam, mixed with a considerable amount of calcareous sand, the latter evidently having been brought into the shelter from the nearby beach, probably to provide a clean living floor.

Layer IIIA $(10-50 \mathrm{~cm})$ : Very dark-grey to black midden deposit, with distinct lenses of compact light-gray ash interspersed. The latter are interpreted as rake-out deposits from nearby combustion features.

Layer IIIB (50-72 cm): Dark reddish-grey cultural deposit lacking ash lenses, mixed with some calcareous sand. 


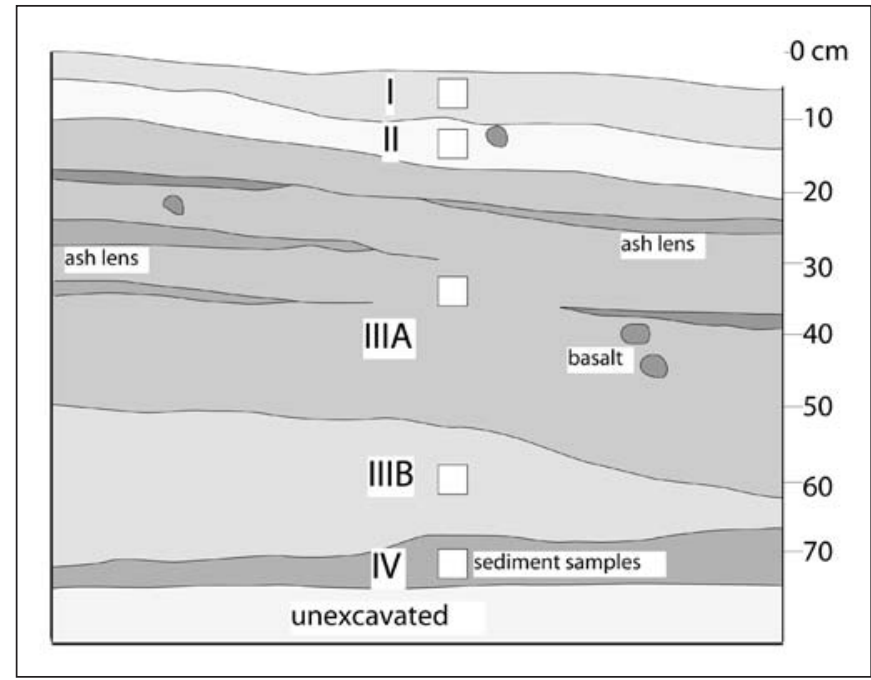

Figure 5. Stratigraphic section of Test Unit 1 in the Nenega-Iti rock-shelter site (AGA-1).

Layer IV $(72+\mathrm{cm})$ : Dark reddish-brown clay with numerous natural cobbles. This layer represents the natural rock-shelter surface before human occupation.

Two radiocarbon dates were obtained from samples excavated from TP-1 at the NenegaIti rock shelter. The uppermost sample (Beta-190116) consisted of Pandanus wood from the interface of Layers I and II, and yielded a calibrated age of AD 1430-1460. The lower sample (Beta-190117), of Hibiscus tiliaceous wood, came from the base of cultural Layer III, and yielded an age of AD 1260-1290. Both of these samples are of relatively short-lived taxa, and should not therefore have any significant in-built age factor. They suggest the cultural deposits in the Nenega-Iti rock shelter were accumulated over about two centuries, from roughly AD 1250 to AD 1450.

On the main island of Mangareva, a rock shelter at Atiaoa on the northwest coast is part of a small valley settlement complex (Conte and Kirch 2004:Figure 3.23). The shelter has a protected surface area of about $4 \mathrm{~m} \times 8 \mathrm{~m}$, and we excavated a single $1 \mathrm{~m}^{2}$ test unit near the rear wall (Figure 6). The stratigraphy of that unit consisted of the following layers:

Layer I: A black, compact, silty clay loam, somewhat disturbed by pig rooting.

Layer II: Very dark-grey silty clay with some calcareous sand admixture, with an earth-oven feature in one part of the unit. This is the primary cultural deposit.

Layer III: Dark reddish-brown clay, with dispersed charcoal particles probably derived from anthropogenic burning in the rock-shelter vicinity.

A single radiocarbon date was obtained from the Atiaoa site, on charcoal from within the earth-oven feature in Layer II (Beta-174777). This yielded a calibrated age of AD 1280-1300, indicating that this deposit is roughly contemporaneous with that of the Nenega-Iti rock shelter on Agakauitai Island.

Other sites excavated by Green in 1959 on the islands of Kamaka and Aukena, as well as the Gatavake site studied by Orliac on Mangareva Island, relate to the same period as the Nenega-Iti and Atiaoa sites, and provide additional information.

\section{Recent-period sites}

The final phase of Mangareva prehistory, before the arrival of Europeans, is represented in our field data by two stratigraphic sections on the main island of Mangareva, at Gaeata and Gatavake, respectively. Both sections reveal a phase of significant erosion of upland slopes and 
deposition of terrigenous sediment on to the coastal plains. The Gaeata deposits also contain subfossil endemic land snails. One radiocarbon sample from Gaeata and two from Gatavake indicate that these depositional events occurred during the 17 th and 18 th centuries.

Drawing on the data recovered from the several sites described above, it is possible to outline in very general terms a sequence of the evolution of the Mangarevan environment over the period of human occupation, beginning about $\mathrm{AD} 1000$ and continuing to the period of European arrival.

\section{Transformation of the terrestrial environment}

\section{Terrestrial gastropods and vegetation cover}

Ideally, the best direct evidence for changes to the vegetation of the Mangareva Islands would come from micro- and/or macro-botanical remains, including pollen and charcoal. However, the islands lack good sites for pollen analysis, although there may be some potential in swampy deposits such as lie behind the dune ridge at Rikitea. Charcoal is abundant in cultural deposits such as Onemea and the rock shelters, and in the future, we hope to exploit this source of data on vegetation change. Another proxy indicator of generalised vegetation conditions, however, may be found in the endemic and indigenous terrestrial gastropods for which the Mangareva group is well known to malacologists. As noted earlier, at least 38 endemic species of land snails are known from sub-fossil specimens in sedimentary contexts; all of these species are extinct today. The specimens were collected in the course of several scientific expeditions, beginning with the 1934 Mangarevan Expedition and continuing with recent work by the Paris Natural History Museum (Cooke 1935; Kondo 1962; Solem 1976; Abdou and Bouchet 2000; Bouchet and Abdou 2001, 2003). To date, however, this malacological work has focused exclusively on the taxonomy of the snails, with virtually no attention to the geomorphological or sedimentary contexts from which the specimens were collected.

In our work, we paid particular attention to the presence of terrestrial gastropods in our archaeological deposits, and thus for the first time, have obtained a sequence of endemic landsnail specimens in dated contexts. The early TAR-6 site at Onemea contains abundant small endodontid snails (large samples obtained from the 2004 excavations will be described and

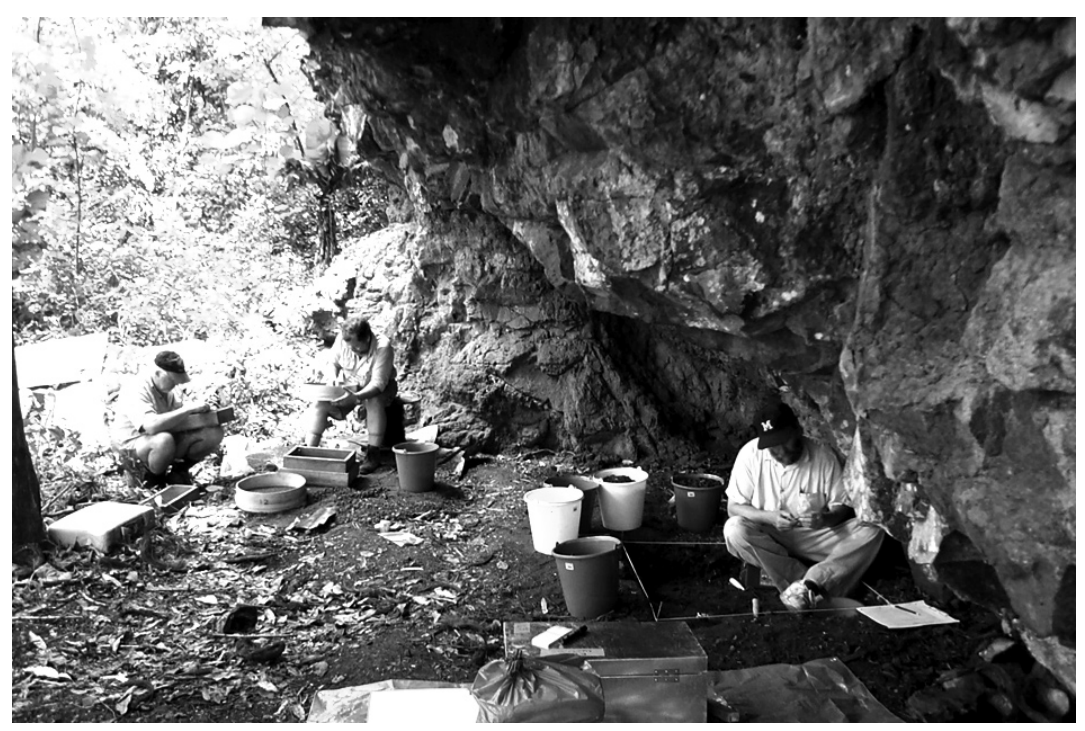

Figure 6. View of the Atiaoa rock shelter (ATA-1) during test excavation in 2001 (A. Anderson, P. Kirch, M. Weisler). 
published elsewhere), as well as significant quantities of the assimineid snail Omphalotropis margarita. The presence of these abundant endemics suggests relatively little disturbance to the local vegetation conditions surrounding the site. The Nenega-Iti and Aitaoa rock shelters, dating to the intermediate phase, both contained representatives of the large endemic genus Gambiodonta (either G. grandis, or a closely related extinct species or subspecies), as well as large quantities of $O$. margarita. Again, the existence of these taxa suggests the continued presence of native forest in the vicinities of these sites. At the late Gaeata site, however, the only endemic present in low frequency was $O$. margarita, which is today extinct as well. Although tentative, these distributions of endemic land snails can be taken as a rough proxy indicator of the persistence of native vegetation through the intermediate phase, with increased deforestation and extinction of gastropods in the late period.

Our sites also contain two species of land snails that were introduced to the islands by Polynesian colonists: Allopeas gracile (Subulinidae) and Lamellidea oblonga (Tornatellinidae). Both of these taxa have been shown by previous studies to have been widely dispersed by Polynesians and other Pacific peoples, presumably adhering to plant materials and/or soil with plants during inter-island voyages (Christensen and Kirch 1981; Kirch 1984:136-37). Allopeas gracile appears in significant quantities in the basal deposits (upper Layer III) of the Onemea site. It and Lamellidea oblonga have both been identified from the late-period deposits at Gaeata; these anthropophilic taxa which inhabit gardens were thus able to survive the deforestation events that led to the extinction of the endemic snails.

\section{Birds}

Even more significant than the temporal patterns of changing frequency of land snails is the evidence from our sites for severe reductions over time in the presence of land and sea birds. Historically, the Mangareva avifauna is highly depauperate in native land birds (other than the introduced chicken and common rock dove, being limited to a kingfisher species also found in the Tuamotus [Halcyon gambieri] and a reed-warbler [Conopoderas caffra]; Lacan and Mougin 1974). Most of the bird taxa known to Mangareva thus consist of sea birds, but as Lacan and Mougin (1974) observe, these are largely confined to the three small, unoccupied, high islands in the southern part of the lagoon (Makaroa, Manui and Motu Teiku). The larger, inhabited islands are notable for the general absence of bird fauna.

Clearly, the situation at the time of initial Polynesian settlement of Mangareva was quite different. Steadman and Justice (1998) previously identified 15 species of sea birds, three species of resident land birds, a migrant shore bird, and the Polynesian-introduced chicken (Gallus gallus) from archaeological samples excavated by Roger Green in 1959. Our excavations add considerably to this inventory, especially thanks to the sample of 153 bird bones (Figure 7) recovered from the early Onemea site (Worthy and Tennyson 2004). The high density of seabird bones in Layer III and to some extent at the base of Layer II in this site suggest that Taravai Island was a significant rookery or nesting site for several species of Procellaridae, especially a species in the genus Pseudobulweria, which today does not exist in Mangareva and indeed has a very restricted distribution in the Pacific. Also present in the early Onemea desposits are three species of Puffinus (shearwaters), one or two species of Pterodroma (petrels), the red-tailed tropic bird (Phaethon rubricauda), and the white tern (Gygis alba). In addition, there are several bones from a species of Ducula (Columbidae), a genus of fruit pigeons with numerous endemic taxa known from archaeological contexts from other Pacific Island groups (Steadman 2006). This hints at the likely presence of an endemic land-bird fauna on the main Mangareva Islands, which further excavations and enlarged sample sizes will hopefully reveal. 
The vertebrate sample from the 'intermediate' phase Nenega-Iti site contrasts markedly with that from the earlier Onemea deposits. (Unfortunately, the vertebrate remains from Atiaoa were lost in transit to the University of Florida and hence are not available for comparison.) From this rock shelter, there were only 13 bird bones, mostly confined to the base of Layer III. Only three taxa were represented: the Pseudobulweria, which dominated the sample with 10 bones, a species of Pterodroma, and a single bone of the brown Noddy (Anous stolidus).

While these patterns need to be augmented by additional samples, one may nonetheless suggest there was a significant decline in the taxonomic richness and frequency of birds over time on the Mangareva Islands. Such patterns of extirpation and extinction of island avifaunas have been well documented for a number of oceanic islands (Steadman 2006), and Mangareva appears to add yet another case of this phenomenon. If the formerly extensive bird populations constituted a significant food resource for the first Polynesian colonists, they also are likely to have played a non-trivial role in the enrichment of soil nutrients through the regular deposition of guano, essential for the maintenance of the terrestrial ecosystem. Thus one may hypothesise that the decimation of these bird colonies, whether directly through human hunting, or indirectly, for example through the introduction of the Pacific rat (Rattus exulans), interrupted this cycle of nutrient enrichment. Combined with forest clearance for horticulture, and possibly climatic factors (Allen 2006), the elimination of a major input source for soil nutrients on old, weathered volcanics may have hastened the deforestation which was so evident at the time of European contact.

\section{Mammals}

The only mammals described ethnographically for Mangareva were pigs and the Pacific rat $(R$. exulans). Pigs, however, were known only from oral traditions, and were not present on the islands at the time of initial European contact (Hiroa 1938:194-195). Green and Weisler (2004), who analysed the vertebrate remains from Green's 1959 excavations, reported abundant rat bones at all sites, but only 11 bones of pig and five bones of dog; clearly, however, pigs and dogs had both been introduced to the islands by Polynesians. Our excavated vertebrate assemblages reinforce this picture of limited quantities of pig and/or dog, with only a single identified premolar of Sus scrofa from the Nenega-Iti site, and a few other fragmentary post-cranial remains of medium mammal which represent either pigs or dogs. The rarity of pig remains in all sites studied to date suggests these animals were never abundant in pre-European times. As Kirch (2000) has suggested, pigs were eliminated in some islands due to their trophic competition with humans for limited horticultural productions, and this appears also to have been the case for Mangareva. The fact that the majority of pig bones recovered by Green on Kamaka Island came from a marae context, or religious site, demonstrates that pigs were a food item reserved for the elite and offered during their rituals.

The bones of the Pacific rat (Rattus exulans) are present in small quantities in Onemea, but are quite abundant in the Nenega-Iti deposits, suggestive of an increase in their populations from the early to intermediate periods. In contrast to the situation in the Tangatatau rock shelter (Site MAN-44)

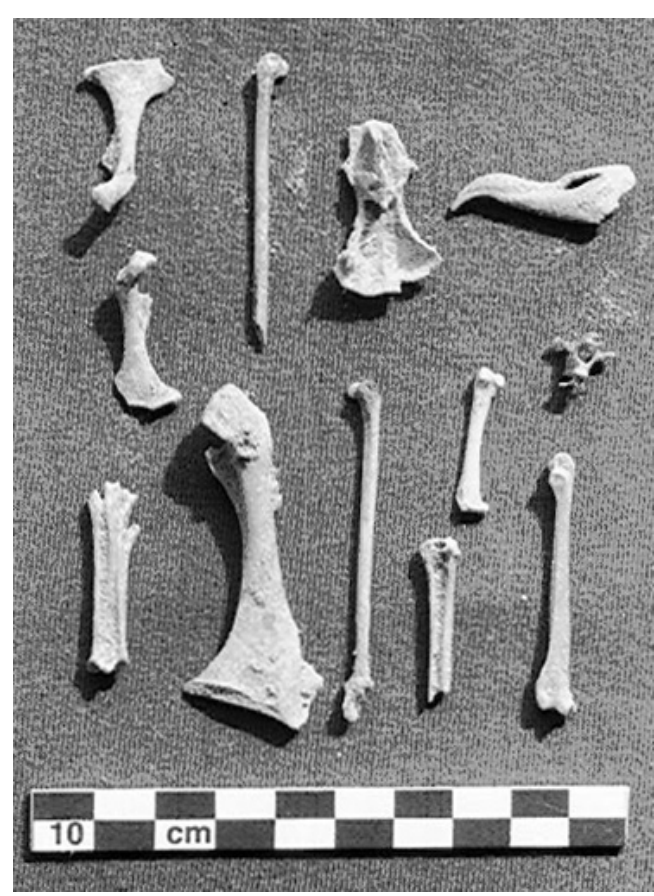

Figure 7. Bird bones from the Onemea site. 
on Mangaia Island (Kirch 1996; Kirch et al. 1995), there are no taphonomic traces (burning or chewing marks) on the Mangareva rat bones, which would seem to confirm Hiroa's statement that rats were not consumed by the Mangarevans (Hiroa 1938). Whereas Mangaia also has a sequence in which pigs were eliminated and there was severe terrestrial resource limitation, in Mangareva one may suppose that the extensive marine resources were sufficient to provide for the protein needs of the human population.

\section{Human impact on marine resources?}

In all of the excavated sites, marine food remains (fish bones and shellfish) constitute the majority of the faunal assemblages. For example, 94 percent of the vertebrate remains at Nenega-Iti, and 64 percent of those at Onemea, consist of fish bones. The most commonly taken fish are the major inshore reef and lagoon species (in the families Scaridae, Balistidae and Serranidae), with very few pelagic fish represented. For both fish and marine molluscs, we have no evidence for significant changes between the different sites, nor between levels of the same site, which might indicate anthropogenic impact on marine resources (e.g. size diminution, or decreasing representation of particular high-value taxa). This is again a significant contrast to the situation in Mangaia, where Butler (2001; and see Kirch et al. 1995) has demonstrated considerable resource depression over time. The relative vastness of the Mangarevan marine and lagoon ecosystem, in comparison with the diminutive land area, may thus have provided a sufficiently rich and resilient resource base such that the small human population never had a significant impact on it. Of course, we again stress that this is a hypothesis to be confirmed by further excavations and enlarged faunal samples.

\section{Conclusion}

Before the arrival of humans (about 900-1000 AD), the Gambier Islands possessed a diverse bird fauna, with at least 19 species, as evidenced by the zooarchaeological assemblage of the Onemea site. As in many other Pacific islands, these bird populations were decimated within several centuries after the arrival of Polynesians, who hunted them, and who presumably also hastened their demise indirectly through the introduction of predatory rats and through the habitat destruction resulting from forest clearance for gardens. Two of these species are extinct today, and others are no longer present in the Gambier archipelago. Among the secondary effects of this major episode of bird extinction and extirpation may have been the curtailing of a critical cycle of nutrient inputs to the terrestrial ecosystem, through the regular deposition of the guano of large sea-bird populations.

As elsewhere in Polynesia, the colonising population introduced a variety of other organisms, not only the Pacific rat and at least two species of land snail that inhabit plants and garden soils, but chickens, pigs and dogs. Naturally, it also introduced the key tree and root crops essential for Polynesian horticulture. The gradual reduction in native-forest cover, presumably correlating with an expansion of human horticultural activity, is mirrored in the gradual reduction in the presence of various taxa of endemic land snails, now entirely extinct, such as the large Gambiodonta cf. grandis which last appears in the upper levels of our intermediate-phase sites. While forest clearance for horticulture was presumably one factor influencing the decline in native-vegetation cover, this is not necessarily the sole cause of the extreme deforestation witnessed in Mangareva in the historic period. We have already alluded to the possible negative effects of the elimination of sea-bird nutrients on islands with five to six million-year-old soils, already limited in such key nutrients as phosphorus. The final phase of near total deforestation of the upper slopes and ridges of the main high islands appears to correlate with a major phase 
of erosion and deposition of terrestrial sediments, evidenced at the recent (17th-18th century) sites of Gaeata and Gatavake. A similar chronology of deforestation has been noted by Orliac and Orliac (2006) for Easter Island, and the timing may not be entirely coincidental.

We would not rule out possible climatic effects, such as those that brought on the Little Ice Age (Allen 2006), although we question whether climate change without the combined effects of human actions would have resulted in the sequence in evidence for either island. Finally, in contrast to the major changes in the terrestrial environment discussed above, thus far we have no evidence for any significant impact on marine resources. The marine resource base may simply have been so extensive and rich in Mangareva that it was resilient to the anthropogenic effects of the limited human population which was capable of being supported on the small and increasingly fragile high islets. In the end, the ethnographic sources indicate that this marine resource base was fundamental to the late-period Mangarevan economy. Where else in Polynesia could the simple act of a fisherman withholding the gift of his catch bring down the ruling chief (Hiroa 1938:76)?

\section{References}

Abdou, A. and P. Bouchet 2000. Nouveaux gastéropodes Endodontidae et Punctidae (Mollusca, Pulmonata) récemment éteints de l'archipel des Gambier (Polynésie). Zoosystema 22:689-707.

Allen, M. 2006. New ideas about Late Holocene Climate Variability in the Central Pacific. Curent Anthropology 47:521-535.

Anderson A. and Y. Sinoto 2002. New Radiocarbon Ages of Colonization Sites in East Polynesia. Asian Perspectives 41:242-257

Anderson A., E. Conte, G. Clark, Y. Sinoto and F.Petchey 1999. Renewed Excavations at Motu Paeao, Maupiti, French Polynesia: Preliminary Results. New Zealand Journal of Archaeology 21:47-65.

Bouchet, P. and A. Abdou 2001. Recent extinct land snails (Euconulidae) from the Gambier Islands with remarkable apertural barriers. Pacific Science 55:121-127.

Bouchet, P. and A. Abdou 2003. Endemic land snails from the Pacific Islands and the museum record: Documenting and dating the extinction of the terrestrial Assimineidae of the Gambier Islands. Journal of Molluscan Studies 69:165-170.

Butler, V.L. 2001. Changing fish use on Mangaia, southern Cook Islands: Resource depression and the prey choice model. International Journal of Osteoarchaeology 11:88-100.

Christensen, C.C., and P.V. Kirch 1981. Nonmarine mollusks from archaeological sites on Tikopia, Southeastern Solomon Islands. Pacific Science 35:75-88.

Conte E. and A. Anderson 2003. Radiocarbon Ages for two sites on Ua Huka, Marquesas. Asian Perspectives 42:155-160.

Conte, E. and P.V. Kirch (eds) 2004. Archaeological Investigations in the Mangareva Islands (Gambier Archipelago), French Polynesia. Contribution No. 62, Archaeological Research Facility. Berkeley: University of California.

Cooke, C.M., Jr. 1935. Report of C. Montague Cooke, Jr., Malacologist and Leader [of the 1934 Mangarevan Expedition]. In H.E. Gregory, Report of the Director for 1934. Honolulu: Bernice P. Bishop Museum Bulletin 133.

Emory, K.P. 1939. Archaeology of Mangareva and Neighboring Atolls. Honolulu: Bernice P. Bishop Museum Bulletin 163.

Fourmanoir, P., J.M. Griessinger and Y. Plessis 1974. Faune ichtyologique des Gambier. Cahiers $d u$ Pacifique 18:543-559. Paris: Fondation Singer-Polignac.

Green, R.C. and M.I. Weisler 2000. Mangarevan Archaeology: Interpretations Using New Data and 40 
Year Old Excavations to Establish a Sequence from 1200 to 1900 AD. University of Otago Studies in Prehistoric Archaeology No. 19. Dunedin.

Green, R.C. and M.I. Weisler 2002. The Mangarevan sequence and the dating of geographic expansion into southeast Polynesia. Asian Perspectives 41:213-241.

Green, R.C. and M.I. Weisler 2004. Prehistoric introduction and extinction of animals in Mangareva, Southeast Pacific. Archaeology in Oceania 39:34-41.

Hiroa, Te Rangi (P.H. Buck) 1938. Ethnology of Mangareva. Honolulu: Bernice P. Bishop Museum Bulletin 157.

Kirch, P.V. 1984. The Evolution of the Polynesian Chiefdoms. Cambridge: Cambridge University Press.

Kirch, P.V. 1996. Late Holocene human-induced modifications to a central Polynesian island ecosystem. Proceedings of the National Academy of Sciences, USA, 93:5296-5300.

Kirch, P.V. 2000. Pigs, humans, and trophic competition on small Oceanic islands. In A. Anderson and T. Murray (eds), Australian Archaeologist: Collected Papers in Honour of Jim Allen, pp. 427-439. Canberra: Australian National University.

Kirch, P.V. 2007a. Hawaii as a model system for human ecodynamics. American Anthropologist 109:8-26.

Kirch, P.V. 2007b. Three islands and an archipelago: Reciprocal interactions between humans and island ecosystems in Polynesia. Earth and Environmental Science Transactions of the Royal Society of Edinburgh 98:1-15.

Kirch, P.V., D.W. Steadman, V.L. Butler, J. Hather, and M.I. Weisler 1995. Prehistory and human ecology in Eastern Polynesia: Excavations at Tangatatau rockshelter, Mangaia, Cook Islands. Archaeology in Oceania 30:47-65.

Lacan, F. and J.-L. Mougin 1974. Les oiseaux de l'archipel des Gambier. Cahiers du Pacifique 18:533-542.

Laval, Père H. 1938. Mangareva: l'Histoire Ancienne d'un Peuple Polynésien. Paris: Librairie

Orliac C. and M. Orliac 2006. La flore disparue de l'île de Pâques. les Nouvelles de l'Archéologie 102: 29-33.

Orliac, M. 2002. Composition et Évolution de la Flore de l'Archipel Gambier du 12è au 19è Siecle. Rapport sur les Travaux de la Mission Archéologique, Avril-Mai 2001. Paris: C.N.R.S.

Orliac, M. 2003. Un aspect de la flore de Mangareva au XIIème siècle (archipel Gambier, Polynésie française. In C. Orliac (ed), Archéologie en Océanie insulaire. Peuplement, sociétés et paysages, pp. 150-171. Editions Artcom.

Richard, G. 1974 Bionomie des mollusques littoraux des baies envasées de l'île de Mangareva. Cahiers du Pacifique No. 18(II):605-614. Paris: Fondation Singer-Polignac.

Salvat, B. 1974. Mollusques des "récifs d'îlots" du récif barrière des îles Gambier. Cahiers du Pacifique No. 18(II):601-603. Paris: Fondation Singer-Polignac.

St. John, H. 1935. Report of Harold St. John, Botanist. In H. E. Gregory, Report of the Director for 1934. Honolulu: Bernice P. Bishop Museum Bulletin 133.

Solem, A. 1976. Endodontoid Land Snails from Pacific Islands (Mollusca: Pulmonata: Sigmurethra). Part I. Family Endodontidae. Chicago: Field Museum of Natural History.

Solem, A. 1983. Endodontoid Land Snails from Pacific Islands (Mollusca: Pulmonata: Sigmurethra). Part 2. Families Punctidae and Charopidae. Chicago: Field Museum of Natural History.

Steadman, D. 2006. Extinction and Biogeography of Tropical Pacific Birds. Chicago: University of Chicago Press.

Steadman, D.W. and L.J. Justice 1998. Prehistoric exploitation of birds on Mangareva, Gambier Islands, French Polynesia. Man and Culture in Oceania 14:81-98. 